\title{
What affects lifelong learning of scientists and engineers?
}

Citation for published version (APA):

de Grip, A., \& Smits, W. (2009). What affects lifelong learning of scientists and engineers?

Researchcentrum voor Onderwijs en Arbeidsmarkt, Faculteit der Economische Wetenschappen. ROA Research Memoranda No. 2 https://doi.org/10.26481/umaror.2009002

Document status and date:

Published: 01/01/2009

DOI:

10.26481/umaror.2009002

Document Version:

Publisher's PDF, also known as Version of record

\section{Please check the document version of this publication:}

- A submitted manuscript is the version of the article upon submission and before peer-review. There can be important differences between the submitted version and the official published version of record.

People interested in the research are advised to contact the author for the final version of the publication, or visit the DOI to the publisher's website.

- The final author version and the galley proof are versions of the publication after peer review.

- The final published version features the final layout of the paper including the volume, issue and page numbers.

Link to publication

\footnotetext{
General rights rights.

- You may freely distribute the URL identifying the publication in the public portal. please follow below link for the End User Agreement:

www.umlib.nl/taverne-license

Take down policy

If you believe that this document breaches copyright please contact us at:

repository@maastrichtuniversity.nl

providing details and we will investigate your claim.
}

Copyright and moral rights for the publications made accessible in the public portal are retained by the authors and/or other copyright owners and it is a condition of accessing publications that users recognise and abide by the legal requirements associated with these

- Users may download and print one copy of any publication from the public portal for the purpose of private study or research.

- You may not further distribute the material or use it for any profit-making activity or commercial gain

If the publication is distributed under the terms of Article $25 \mathrm{fa}$ of the Dutch Copyright Act, indicated by the "Taverne" license above, 


\title{
What affects lifelong learning of scientists and engineers?
}

\author{
Andries de Grip \\ Wendy Smits \\ ROA-RM-2009/2 \\ February 2009
}

Research Centre for Education

and the Labour Market

P.O. Box 616

6200 MD Maastricht

The Netherlands

E-mail: $\quad$ secretary@roa.unimaas.nl

Internet: $\quad$ www.roa.unimaas.nl

Maastricht University

Faculty of Economics and Business Administration 
The ROA Research Memorandum Series was created in order to make research results available for discussion, before those results are submitted for publication in journals.

Sec09.013.pdf 
ROA-RM-2009/2 » http://www.roa.unimaas.nl/resmem.htm

\section{Abstract}

\section{What affects lifelong learning of scientists and engineers? ${ }^{1}$}

This paper greatly enriches the discussion on the determinants of lifelong learning of scientists and engineers (S\&Es). In our analysis, which is based on a survey among S\&Es in the Netherlands, we take account of both formal training and different modes of informal learning. We find that S\&Es employed in firms which apply innovative production processes more often participate in formal training and also benefit from the informal learning potential of their jobs. Therefore, public policies that stimulate process innovation also prevent skills obsolescence among S\&Es. However, lifelong learning is not triggered in firms with many product innovations. S\&Es who are employed in firms which operate on highly competitive markets also participate in formal training less often. The same holds for S\&Es employed in small firms, although the latter compensate their lower participation in formal training by more hours of self-teaching. S\&Es employed in jobs which require a high level of technical knowledge have more formal training, whereas those employed in jobs which require more general skills are significantly more involved in informal learning. Furthermore, older S\&Es with long firm tenures participate in formal training less often and have fewer opportunities for learning in their jobs. Therefore, their competence level is at risk.

Andries de Grip

ROA, Maastricht University and IZA

P.O. Box 616

6200 MD Maastricht

The Netherlands

a.degrip@roa.unimaas.nl
Wendy Smits

Statistics Netherlands and ROA

P.O. Box 4481

6401 CZ Heerlen

The Netherlands

wmts@cbs.nl

1. The authors thank Annemarie Nelen and Jasper Van Loo for helpful comments on earlier drafts of this paper. 



\section{Introduction}

The durability of knowledge in the fields of science and engineering is much shorter than in other academic fields (McDowell, 1982). Moreover, the diffusion of information technology (IT) (e.g. Machin and Van Reenen (1998); Lavoie, Roy and Therrien, 2003) and organizational change (e.g. Piva and Vivarelli, 2004) in particular increase skill demands. Other studies found that technological change also affects the relative demand for different skills (Dickerson, and Green, 2004). As in many other fields, scientists and engineers (S\&Es) need to acquire "soft skills" in addition to their technical skills (Kumar and Kent Hsiao, 2007). Lifelong learning is therefore crucial for the productivity of S\&Es.

Human capital investments do not only consist of formal training courses but also include informal learning. Formal and informal training may also interact. Skills taught in formal training courses must be transferred to the workplace through learning-by-doing (Burke, and Baldwin, 1999). In economic literature, there are hardly any studies on the factors related to informal learning, which is usually only proxied by work experience (Mincer, 1974). Borghans, Golsteyn, and De Grip (2007) found that Dutch workers spend on average 31\% of their working time on activities from which they learn on the job. This makes it obvious that informal learning should be included in studies on post-initial human capital development. Lavoie and Finnie (1998) argued that this holds in particular for engineers because technology is based on knowledge and skills that are largely tacit.

In this paper, we will analyze the determinants of lifelong learning of S\&Es. In our analyses, which are based on a survey of S\&Es with a tertiary education background in the Netherlands, we will take account of both investments in formal training and different modes of informal learning, such as learning from colleagues in the workplace, self-teaching and having tasks from which one can learn.

Whereas most studies on lifelong learning only focus on the relationships between particular worker characteristics and training participation, we will include employee characteristics as well as firm and job characteristics in our analyses (cf. Shields, 1998). With respect to the firm and job characteristics, we will include among others the skill demands of the job in which one is employed, and the 
innovativeness of the firm and the severity of competition in a firm's sales markets. By including the various skill demands of the job in which a scientist or engineer is employed, we are able to analyze which kind of skill demands are related to higher training participation or specific modes of informal learning. We will distinguish here between technical, general, commercial, management, and advanced IT knowledge and skills. The indicators on the innovativeness of the firm enable us to identify to what extent S\&Es who are employed in firms that are highly innovative with respect to in the introduction of product and process innovations as well as organizational innovations, have more opportunities to develop their human capital, as suggested, for example, by Neuman \& Weiss (1995).

The paper will proceed as follows. Section 2 describes the relevant literature to which this paper contributes, and discusses the various possible determinants of human capital investments that we will include in this paper. Section 3 describes the data, and defines the variables we use in our analyses. In Section 4, we will present the estimation results. Section 5 concludes.

\section{Determinants of human capital investments}

\section{Literature}

In economic literature, human capital theory offers the theoretical framework for human capital investments in the workplace: Both firms and workers weigh the costs and benefits of investing in training (Becker, 1964). Formal training as well as informal learning contribute to the employees' productivity. The benefits of investments in training are therefore related to the working time during which firms can benefit from workers' higher productivity, and workers can benefit from higher future earnings. This explains why younger workers who are at the beginning of their careers participate more often in both formal training and informal learning activities than older workers. Moreover, human capital investments are higher for full-time workers than for part-time workers. And, last but not least, the benefits of human capital investments of workers with higher learning abilities outweigh the benefits of investments in workers with lower 
abilities. This explains the complementarity between the benefits of investments in initial education, and post-initial formal training and informal learning (e.g. Heckman, 1999).

With respect to the investment costs, human capital theory distinguishes between the direct costs (learning material, costs of trainers, etcetera) and the indirect opportunity costs of (working) time in which a worker is not or less productive. In general, both direct and indirect costs of investments in formal training are higher than investments in informal learning. There are also differences in the costs of the various modes of informal learning. Particularly, learning-bydoing induces opportunity costs in terms of forgone working time, whereas selfteaching usually affects leisure time instead of working time.

In economic literature, there are many studies that analyze the relationships between personal, job or firm characteristics and the participation of employees in formal training courses. Most studies focus on the relationships with personal characteristics, and confirm the expectations from human capital theory. Several studies show that higher educated workers participate in post-initial training more often than those who are lower skilled (e.g. Shields, 1998; OECD, 1999). There are also many studies which show that training participation is negatively related to workers' age, tenure, and being employed in a temporary or part-time job (e.g. OECD, 1999; Bassanini et al. 2005). Some studies found that male workers have a higher training incidence than female workers (OECD, 1999), whereas other studies found the opposite (Bassanini et al. 2005). Several studies found evidence for the complementarity between investments in initial education and post-initial formal training (see Bassanini et al. (2005) for an overview). However, although a higher level of initial education is associated with more participation in formal training, training also enables workers to bridge the skill gaps they have in their jobs (e.g. Smoorenburg and Van der Velden, 2000).

Several studies on the determinants of training participation include basic firm characteristics, such as firm size, and sector of industry. All of these studies found that training participation is much higher in large firms than in small and mediumsized firms. (e.g. OECD 1999; Bassanini et al. 2005). Lynch and Black (1998) 
found a positive relation between training participation and the quality of the job, as indicated by being employed in a "high performance workplace". Other studies emphasize that firms may indeed gain from incorporating investments in the training of their workforce in a consistent human resource system, because this may reduce quit rates and therefore increase the returns on training (e.g. Ichniowski \& Shaw, 2003). Finally, several studies found evidence for a positive relationship between technological innovations and training participation. Acemoglu (1997) referred to a number of studies which showed that an efficient adoption of new technologies is attributed to effective training strategies, whereas Groot and De Grip (1991) and Bresnahan et al. (2002) more specifically found that the introduction of new information technology increases training participation of a firm's workforce.

Due to a lack of adequate data on informal learning, there are hardly any studies in economic literature that focus on the determinants of informal learning. In human capital literature, informal learning is traditionally proxied by including the experience of workers in the labour market and their job tenure in earnings functions (cf. Mincer, 1974). Arrow (1962) was one of the first authors who emphasized the importance of unstructured workplace learning. He was concerned with finding the missing explanation for the part of economic growth that cannot be explained by increases in the capital-labour ratio. Arrow argued that this missing explanation is the increase in knowledge, including technological knowledge, which enables firms to optimize their production processes. He stated that this increase in knowledge is acquired through 'learning by doing', which is an automatic by-product of the regular production process of a firm.

This learning by doing is anything but random. Jobs may be deliberately structured so as to provide learning opportunities (e.g. Eraut, 2000). The learning potential of the job (Rosen, 1972) is likely to be greatest in cases where the learning of new skills is most necessary, which is in those jobs where skill requirements are changing rapidly. Whereas jobs characterized by repetitiveness, hierarchical control mechanisms and low levels of autonomy may stifle learning opportunities for workers, more complex jobs with shifting job contents offer ample opportunities 
for informal learning (Allen and De Grip, 2007). From the perspective of the worker, accepting a job with a high learning potential can be a good strategy to maximize lifetime income, so in their early careers, workers may apply for a job with a high learning potential, as such a job will be a good stepping stone for their later careers. Sicherman and Galor (1990) also developed Rosen's theoretical work in their theory on career mobility. In their model, part of the returns to initial education is in the form of higher probabilities of occupational upgrading within or across firms, due to the learning potential of the job. When workers opt for jobs with a high learning potential, their wages will be lower, but their opportunities for upward career mobility will be higher. Examples of such jobs are trainee jobs in large firms.

Nelen and De Grip (2008) defined informal learning as the fraction of working time in which a worker has tasks from which he or she can learn. They found that part-time and full-time workers have similar fractions of working time in which they have tasks from which they can learn. However, only for full-time workers informal learning is positively related to human resource practices of the firm, such as giving feedback and participation in team meetings. Borghans et al. (2007) found that informal learning measured as the number of hours in which a worker has tasks from which he or she can learn, is negatively correlated to a worker's age, and positively related to a worker's imagination of his or her future career, anxiety, organizational change, and a hectic private life. Yeh (2005) analyzed the relationship between self-teaching and the career stages of older engineers in China. He found that engineers in middle-management positions have lower rates of selfteaching than "on-track careerists" who have been promoted to higher related management positions.

In other studies, informal learning is much more implicit. Sicherman (1991) found that occupations, in which the returns to schooling are lower, have higher opportunities for upward mobility. This confirms the hypothesis of the "career mobility" model developed by Sicherman and Galor (1990). Bartel and Sicherman (1993) related on-the-job learning to technological change. They found that workers, who are employed in sectors of industry with high rates of gradual 
technological change, retire later . Although the workers in these sectors of industry face more skill obsolescence due to the diffusion of technological developments, the net effect of technological change on their human capital is positive, because they continuously acquire new skills related to new technologies.

Informal learning is also at the heart of the economic literature on the emergence of "High Performance Workplaces". Lindbeck and Snower (2000) argued that High Performance Workplaces increase the demand for multi-skilled workers (cf. Coates et al. 2007). This induces a shift from "intratask learning" to "intertask learning" in the workplace. This intertask learning takes place mainly through tasks rotation within teams. Lindbeck and Snower stated that intertask learning not only refers to acquiring a broader range of technical skills, but also includes the improvement of a worker's "people skills", and problem-solving skills.

Lavoie and Finnie (1998, p.54) emphasized the importance of informal learning for engineers because "technology is accumulated through different learning processes or conversely, can depreciate if those processes are not present." However, their analysis only focuses on the depreciation risks by documenting the proportion of Canadian engineering graduates in various potentially "at-risk" situations, such as being unemployed, employed in a part-time or temporary job, and being employed in a job in which one's technical skills are not used to a significant degree. Their analysis also suggests that engineering graduates who go directly into management jobs use their engineering skills less than others and "miss the opportunity of developing experience-based tacit knowledge." (Lavoie and Finnie, 1998, p.67).

\section{Possible determinants of human capital investments of SeEs}

In this study, we analyze to what extent the different modes of human capital investments of S\&Es are associated with employee characteristics or job- or firmrelated characteristics. The personal and career-related factors that we include in our analysis are related to the cost-benefit framework delivered by human capital theory. This includes the S\&Es' level of education in order to test whether postinitial human capital investments are complementary to the level of initial 
education. We also include several career-related variables on general work experience, firm tenure, and job tenure. These variables indicate to what extent human capital investments are concentrated at the beginning of the career and/or at the beginning of an appointment in a firm or job. We analyze to what extent the skill-gaps that $S \& E$ s perceive to have in their jobs, stimulate them to invest further in their human capital (cf. Smoorenburg \& Van der Velden, 2000). Economic literature gives hardly any answers to the question whether formal training and informal learning are differently affected by particular determinants of human capital investments. However, differences may arise from the fact that workers have more possibilities for investing in informal learning without creating any additional costs for their employer. This holds in particular for self-teaching outside working time.

We also include in our analyses several job characteristics and various skills required in the job. These variables indicate to what extent human capital investment is driven by the job in which someone is employed. Managerial jobs probably provide for the acquisition of many non-technical skills not learned in initial education. We analyze therefore whether S\&Es with management tasks participate in formal training and/or informal learning more often. We also take account of the different types of knowledge and skills required in the job. We distinguish between technical knowledge and skills and various non-technical skills (cf. Dickerson \& Green, 2004). Literature does not give any explicit hypotheses on whether these skills are usually acquired through formal training or informal learning, although the literature on the High Performance Workplace emphasizes the importance of informal learning from colleagues and by doing tasks from which one can learn. Borghans et al. (2007) showed that by far the greater part of lifelong learning is informal learning. More in general, we may expect that the various modes of lifelong learning are substitutes when it comes to acquiring a particular skill level. Our analyses therefore show which modes of learning are the most relevant ones for acquiring particular skills.

Finally, we analyze to what extent human capital investments of S\&Es are associated with particular firm characteristics. We focus on product market 
characteristics, the innovativeness of the firm and firm size. S\&Es who are employed in firms that sell their products in highly competitive and instable product markets, probably participate in formal training less often, since both firm and employees may be reluctant to invest in human capital because of the less stable employment relations. This is probably less relevant for informal learning because in that case investments costs are lower. From previous studies we may expect that S\&Es who are employed in highly innovative firms, participate in formal training more often, and also learn more at work because they continuously acquire new skills related to the new technologies (Bartel and Sicherman, 1993). As mentioned above, several studies found that training participation is negatively related to firm size. However, employees of small firms may compensate this lower participation in formal training by a larger participation in informal learning at the workplace or by self-teaching at home.

\section{Data and descriptive statistics}

The data used for our analysis were collected by means of an internet survey among Dutch Scientists and Engineers with a Bachelors or Masters degree at the end of 1996. All members of the Royal Institute of Engineers in the Netherlands (KIVI NIRIA) plus the subscribers of the weekly professional journal for scientists and engineers (Technisch Weekblad) were approached by e-mail and invited to participate in the survey. KIVI NIRIA is a professional organization that promotes the interests of Dutch scientists and engineers and provides services that assist members with the development of their professional careers, for example by giving individual advice on salary negotiations. KIVI NIRIA members received e-mail from (the director of) KIVI NIRIA which explained the aim of the survey and contained a link to the survey website. Moreover, subscribers of Technisch Weekblad received an e-mail on behalf of the editor. Since only members of the KIVI NIRIA and the subscribers of Technisch Weekblad were selected, our sample is selective in that particularly those S\&Es who opted for a technical career will be represented in the survey. Twenty gift tokens of 50 euros each were raffled among 
the respondents. Respondents were also told that upon completion of the questionnaire, they would be offered a free subscription to Technisch Weekblad and $\mathrm{C} 2 \mathrm{~W}$, a professional journal on chemistry, life sciences and process technology. The response rate was about 20\%. Approximately 6,000 respondents started the interview. Almost one third of the respondents had not graduated yet or had already retired, rendering 4,396 individuals eligible for the study.

The survey included questions about the field of study, year of graduation, type of job, organization of employment (number of employees, sector of industry) and earnings. The following questions were used to measure formal training and selfteaching:

- How many hours did you spend on training courses (excluding self-teaching) during the last 12 months?

- How many hours did you spend on self-teaching during the last 12 months (For example by studying manuals, textbooks or software)?

The questionnaire also asked how many of these hours could be spent during working times. Other types of informal learning include learning from colleagues and learning-by-doing. These types of learning were measured with the following questions:

- How many hours do you usually spend each week on tasks from which you can learn?

- How many hours do you usually spend with your colleagues each week in order to learn from them (for example by demonstrating you certain tools or techniques, explaining you things, giving advice, etc.) 
Table 1

Description of the variables

Mean St. dev.

\section{Formal and informal learning}

Training

$28.21 \quad 50.72$

Self-teaching

$26.25 \quad 93.60$

Learning from colleagues

$169.47 \quad 236.30$

Performing tasks from which one can learn

$386.03 \quad 420.04$

\section{Personal and career characteristics}

$\begin{array}{lrr}\text { Master degree } & 0.50 & 0.50 \\ \text { Female } & 0.08 & 0.28 \\ \text { Work experience (years) } & 14.47 & 10.40 \\ \text { Work experience2 (years2) } & 317.54 & 372.63 \\ \text { Firm tenure (years) } & 8.31 & 8.04 \\ \text { Firm tenure2 (years2) } & 133.68 & 236.61 \\ \text { Knowledge and skill level in previous year ("skill gap") } & 78.35 & 17.92\end{array}$

\section{Job characteristics}

No management tasks

$0.42 \quad 0.49$

Spending less than $75 \%$ of working time on management tasks

$0.50 \quad 0.50$

Spending more than $75 \%$ of working time on management tasks

$0.08 \quad 0.28$

\section{Skill demands}

Required level of technicial knowlegde and skills

$7.62 \quad 2.05$

Required level of general knowlegde and skills

$6.96 \quad 1.23$

Required level of commercial and financial knowlegde and skills

$5.73 \quad 2.37$

Required level of advanced IT knowlegde and skills

$5.73 \quad 2.70$

Required level of management and planning knowlegde and skills

7.39

\section{Product market characteristics}

Degree of competition in product markets

3.78

Degree of competition on quality instead of price

$3.76 \quad 1.03$

Degree of demand instability in product markets

3.01

1.01

\section{Innovativeness of the firm}

Degree of product innovation

Degree of process innovation 
Table 1 (continued)

Description of the variables

Mean St. dev.

$\begin{array}{lll}\text { Firm size } & & \\ <10 \text { employees } & 0.11 & 0.31 \\ 10-24 \text { employees } & 0.05 & 0.21 \\ 25-49 \text { employees } & 0.05 & 0.23 \\ 50-99 \text { employees } & 0.07 & 0.25 \\ 100-249 \text { employees } & 0.09 & 0.29 \\ 250-999 \text { employees } & 0.16 & 0.36 \\ 1000 \text { or more employees } & 0.48 & 0.50\end{array}$

To obtain comparable figures for training and self-teaching on the one hand, and learning-by-doing and learning from colleagues on the other hand, we converted the latter into yearly hours by assuming 40 working weeks pro year. Table 1 shows that by far most of the working time in which S\&Es further invest in their human capital is spent on learning-by-doing (on average 386 hours in a year). S\&Es also spend quite some time on learning from their colleagues (on average 169 hours in a year). Far less working time is devoted to participation in formal training courses (on average 28 hours in a year) and self-teaching (26 hours in a year).

Table 1 also reports the means and standard deviations of the main explanatory variables of our analysis. The table shows that half of the S\&Es has a master degree and only $8 \%$ is female. On average, they have about 14 years of work experience and 8 years tenure in the firm in which they are employed. The survey also included a range of questions on competencies. First, respondents had to rate their overall knowledge and skill level in the previous year, with the reference that the skills required for optimal performance in their job is 100 . Table 1 shows that respondents give themselves an average rate of about 78 . The table also shows that $42 \%$ of S\&Es do not have any management tasks, whereas $8 \%$ spend more than $75 \%$ of their working time on management tasks.

Respondents also had to rate the skills demanded in their current jobs on a tenpoint scale (which is the usual grading system in the Dutch educational system) for 
a large number of skills, including technical, commercial and financial, (advanced) IT, management and planning, and general skills, such as analytical thinking and problem solving. As it was expected that these questions might be perceived as awkward by some of the respondents, they were optional. About one third of the respondents completed the questions on competences. Table 1 shows that particularly the skill demands for technical knowledge and skills, and management and planning knowledge and skills are relatively high. The latter is remarkable, because $42 \%$ of the S\&Es have no management tasks at all. Apparently, this does not mean that they need no organizational and planning skills in their jobs. The average skill demands for advanced IT and commercial and financial knowledge are relative low. As indicated by the high standard deviations, the latter is due to the fact that for a large number of $S \& E s$ these skills are hardly relevant in their jobs.

Respondents also indicated on five-point scales the product market characteristics and the innovativeness of the firm in which they were employed. On average, competition in product markets is high, with an emphasis on product quality. With respect to the innovativeness of the firm, particularly the degree of product innovation is high. Finally, the table shows that almost half of all S\&Es is employed in very large firms, whereas $28 \%$ is employed in firms with less than 100 employees.

\section{Correlations between formal training and informal learning}

Several studies show that formal training and informal learning are complements instead of substitutes (e.g. Loewenstein and Spletzer, 1999). Table 2 shows that this also holds for S\&Es, although most correlation coefficients are low. Hours of formal training are moderately correlated to the various modes of informal learning. The same holds for the correlation between self-teaching and the two other modes of informal learning. However, doing tasks from which one can learn is highly correlated to learning from colleagues. This shows that informal learning of S\&Es is fostered in particular by the combination of performing challenging tasks and peer feedback. 
Table 2

Correlation coefficients between formal training and modes of informal learning

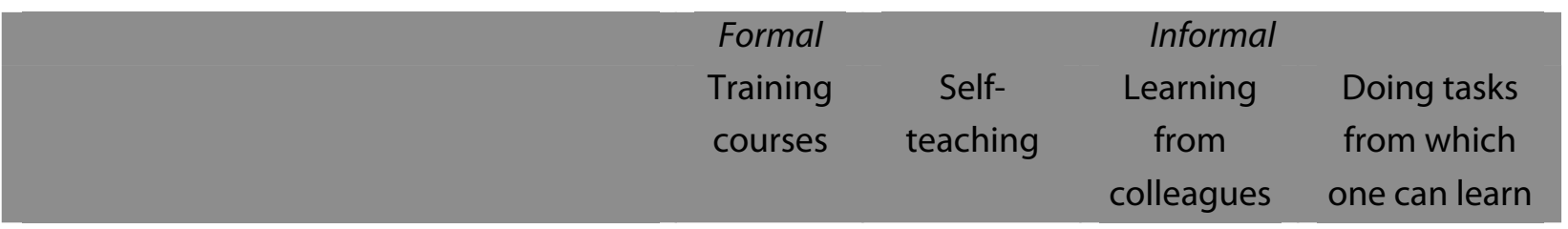

\section{Training courses}

Self-teaching

Learning from colleagues

Doing tasks from which one can learn

* significant at $1 \%$ level

\section{Estimation results}

We estimate the determinants of formal training and informal learning by means of tobit analyses. We apply tobit analyses because substantial numbers of S\&Es do not participate in formal training or some of the modes of informal learning. This particularly holds for self-teaching (56\% of non-participants) and formal training (36\% of non-participants).

\section{Formal training}

The first column of Table 3 reports the estimation results on formal training. Within this fairly homogeneous group of higher skilled S\&Es, there are hardly any relationships between personal and career characteristics and the participation in formal training. Only work experience is negatively related to the number of training hours. Training participation is also related to the kind of skills demanded in the job. S\&Es who are employed in jobs with high demands for technical knowledge and skills, advanced IT, or management and planning knowledge and skills, show a higher participation rate in training courses, whereas those employed in jobs which require a high level of commercial and financial knowledge and skills participate in training less often. Moreover, S\&Es who are employed in firms that face severe competition in their product markets have lower rates of formal training than those who are employed in firms that face less competition. 
Table 3

Determinants of formal training and informal learning

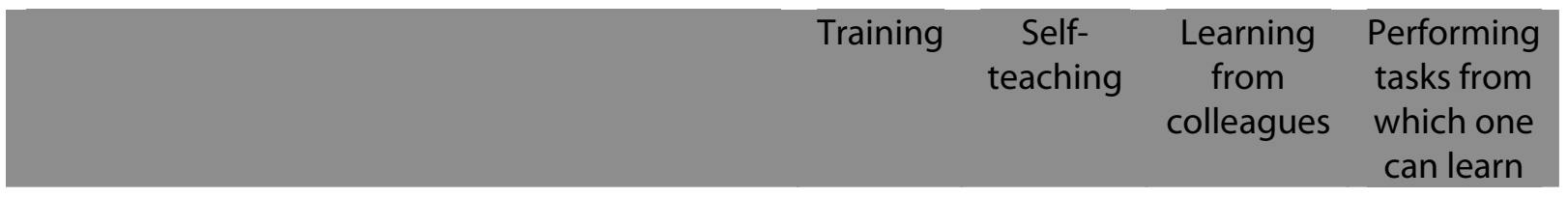

\begin{tabular}{lcccc} 
Personal and career characteristics & & & & \\
Master degree & 4.050 & -2.687 & -25.411 & 33.999 \\
& $(1.28)$ & $(0.45)$ & $(2.24)^{* *}$ & $(1.71)^{*}$ \\
Female & -0.418 & -28.886 & 46.793 & 3.024 \\
& $(0.06)$ & $(2.16)^{* *}$ & $(1.95)^{*}$ & $(0.07)$ \\
Work experience (years) & -1.472 & -1.675 & 0.304 & -4.332 \\
& $(2.27)^{* *}$ & $(1.41)$ & $(0.13)$ & $(1.08)$ \\
Work experience ${ }^{2}$ (years ${ }^{2}$ ) & 0.014 & 0.058 & -0.015 & 0.104 \\
& $(0.80)$ & $(1.76)^{*}$ & $(0.23)$ & $(0.94)$ \\
Firm tenure (years) & 0.698 & 0.066 & -5.982 & -6.935 \\
& $(1.05)$ & $(0.05)$ & $(2.55)^{* *}$ & $(1.68)^{*}$ \\
Firm tenure ${ }^{2}$ (years ${ }^{2}$ ) & -0.024 & 0.016 & 0.186 & 0.131 \\
& $(1.10)$ & $(0.40)$ & $(2.38)^{* *}$ & $(0.96)$ \\
Knowledge and skill level in previous year & -0.147 & -0.490 & -1.358 & -3.156 \\
("skill gap") & $(1.44)$ & $(2.62)^{* * *}$ & $(3.71)^{* * *}$ & $(4.99)^{* * *}$ \\
\hline & & & & \\
Job characteristics & & & & \\
No management tasks & -8.569 & -0.926 & -55.684 & -85.631 \\
(ref.: >75\% management tasks) & $(1.34)$ & $(0.08)$ & $(2.41)^{* *}$ & $(2.13)^{* *}$ \\
Spending less than 75\% of working time on & -6.930 & -1.286 & -21.745 & -80.053 \\
management tasks & $(1.20)$ & $(0.11)$ & $(1.05)$ & $(2.22)^{* *}$ \\
\hline & & & & \\
\hline Skill demands & & & & \\
Required level of technical knowledge and skills & 1.970 & 0.588 & 2.550 & 14.554 \\
& $(1.99)^{* *}$ & $(0.33)$ & $(0.73)$ & $(2.37)^{* *}$ \\
Required level of general knowledge and skills & -1.753 & 16.332 & 21.590 & 43.803 \\
& $(0.86)$ & $(4.28)^{* * *}$ & $(2.93)^{* * * *}$ & $(3.43)^{* * *}$ \\
Required level of commercial and financial & -1.780 & -3.394 & -1.138 & -8.779 \\
knowledge and skills & $(2.00)^{* *}$ & $(2.03)^{* *}$ & $(0.36)$ & $(1.57)$ \\
Required level of advanced IT knowledge and & 1.634 & 0.137 & -1.667 & -1.072 \\
skills & $(2.42)^{* *}$ & $(0.11)$ & $(0.70)$ & $(0.25)$ \\
Required level of management and planning & 4.006 & -12.020 & 4.827 & 10.884 \\
knowledge and skills & $(2.23)^{* *}$ & $(3.61)^{* * *}$ & $(0.75)$ & $(0.98)$ \\
& & & &
\end{tabular}


Table 3 (continued)

Determinants of formal training and informal learning

\begin{tabular}{|c|c|c|c|}
\hline Training & $\begin{array}{c}\text { Self- } \\
\text { teaching }\end{array}$ & $\begin{array}{l}\text { Learning } \\
\text { from } \\
\text { colleagues }\end{array}$ & $\begin{array}{l}\text { Performing } \\
\text { tasks from } \\
\text { which one } \\
\text { can learn }\end{array}$ \\
\hline
\end{tabular}

\section{Product market characteristics}

Degree of competition in product markets

$\begin{array}{cccc}-3.459 & 5.275 & 0.463 & -19.889 \\ (2.00)^{* *} & (1.58) & (0.07) & (1.84)^{*} \\ 1.200 & 2.730 & -8.560 & -15.889 \\ (0.78) & (0.92) & (1.54) & (1.64) \\ -3.230 & -3.477 & -4.418 & -6.240 \\ (2.07)^{* *} & (1.17) & (0.79) & (0.64)\end{array}$

\section{Innovativeness of the firm}

Degree of product innovation

$\begin{array}{cccc}-5.498 & 5.215 & 11.776 & 26.534 \\ (3.22)^{* * *} & (1.58) & (1.89)^{*} & (2.46)^{* *} \\ 4.091 & 1.105 & -3.782 & -6.533 \\ (2.37)^{* *} & (0.34) & (0.61) & (0.61) \\ 5.713 & 1.819 & 13.476 & 7.179 \\ (3.42)^{* * *} & (0.58) & (2.28)^{* *} & (0.70) \\ 1.288 & -3.229 & -6.330 & -15.717 \\ (0.85) & (1.12) & (1.16) & (1.66)^{*}\end{array}$

Firm size (ref.: firms < 10 employees)

10 -24 employees

$\begin{array}{llll}20.667 & -24.658 & 40.936 & 27.603\end{array}$

25-49 employees

(1.62)

(1.27)

(1.03)

27.603

25.148

$-44.481$

$-3.425$

$(0.40)$

$(1.98)^{* *}$

$(2.27)^{* *}$

$-13.923$

50-99 employees

31.553

$-53.857$

(0.09)

$(0.20)$

$(2.61)^{* * *}$

$(2.80)^{* * *}$

3.128

0.396

100-249 employees

44.033

$-39.536$

(0.08)

$(0.01)$

$(3.74)^{* * *}$

$(2.17)^{* *}$

7.309

4.075

250-999 employees

47.588

$-53.632$

(0.20)

$(0.06)$

$(4.20)^{* * *}$

$(3.09)^{* * *}$

10.464

$-4.610$

1000 or more employees

59.810

$-48.272$

(0.31)

(0.08)

$(5.50)^{* * *}$

$(2.97)^{* * *}$

22.434

10.127

Controls for sector of industry are included

Constant

$\begin{array}{cccc}-115.132 & 85.289 & 136.603 & -312.528 \\ (1.30) & (0.58) & (0.40) & (0.61) \\ 1421 & 1352 & 1425 & 1467\end{array}$

Observations

Absolute value of $\mathrm{t}$ statistics in parentheses

* significant at $10 \%$; ${ }^{* *}$ significant at $5 \%$; ${ }^{* * *}$ significant at $1 \%$

1 It should be noted that a higher learning potential, in this respect, can also refer to a higher participation in formal training

2 Bartel and Sicherman (1993) found a similar effect for older workers who have been employed in jobs in which it takes more time to become fully qualified. 
We also find that S\&Es who are employed in firms with high degrees of (technical) process and organizational innovation, participate in formal training courses more often, whereas those employed in a firm with a high degree of product innovation participate in training less often. As shown in many other studies, firm size is positively related to the number of training hours.

\section{Self-teaching}

The second column of table 3 reports the results of a tobit analysis on the determinants of the number of hours S\&Es spend on self-teaching. Estimation results show that female S\&Es spend fewer hours on self-teaching than males. Moreover, those who perceive to have a skill gap appear to upgrade their skill level by self-teaching. The participation in self-teaching is also related to the kind of skills demanded in the job. Particularly high demands of general knowledge and skills appear to stimulate self-teaching. Conversely, those employed in jobs with high demands for commercial and financial skills or management and planning skills have significantly lower rates of self-teaching. Self-teaching appears not to be related to job characteristics nor product market characteristics and the innovativeness of the firm. However, S\&Es who are employed in smaller firms seem to compensate their lower rate of participation in formal training by more hours of self-teaching.

\section{Learning from colleagues}

The third column of table 3 shows the estimation results of a tobit analysis on the number of hours S\&Es spend with colleagues who give them advice or demonstrate work practices. Graduates with a Bachelors degree appear to participate more often in this mode of informal learning than graduates with a Masters degree. The same holds for female S\&Es, although here the coefficient is only weakly significant. As could be expected, S\&Es with a higher firm tenure less often learn intentionally from their colleagues. However, we do not find these relationships for work experience in general. The S\&Es who perceive to have a skill gap also attempt to upgrade their skill level by deliberately learning from their 
colleagues. Remarkably, those who have no management tasks spend less time learning from their colleagues. Learning from colleagues is less related to the kind of skills demanded in the job. Estimation results only show a positive relationship with the level of general skills demanded in the job. Product market conditions and firm size are not significantly related to learning from colleagues either. However, the estimation results show that this mode of informal learning occurs more often when respondents are employed in firms with high degrees of product innovation and organizational innovation, although the former is only weakly significant.

\section{Tasks from which one can learn}

The last column shows the results from a tobit analysis in which the number of hours spent on tasks from which one can learn is the dependant variable. Estimation results show that this mode of informal learning is more important for graduates with a Masters degree than for graduates with a Bachelors degree. Moreover, S\&Es who perceive to have a skill gap also seem to upgrade their skill level by doing tasks from which they can learn. However, those who have no management tasks less often perform tasks from which they can learn than S\&Es who mainly have management tasks. The same holds for S\&Es who spend less than $75 \%$ of their working time on management tasks. The kinds of skills demanded in the job are also related to learning-by-doing. S\&Es who are employed in jobs which require a high degree of technical knowledge and skills or general knowledge and skills, spend more time on tasks from which they can learn. Moreover, this mode of informal learning is related to product market characteristics and the innovativeness of the firm. S\&Es who are employed in firms that face severe competition in their product markets, more often have jobs with a lower learning potential, although this relationship is only weakly significant. S\&Es who are employed in firms with a high degree of product innovation spend significantly more time on tasks from which one can learn, whereas those employed in firms that are merely followers of existing innovations have fewer opportunities for learning-by-doing. Again, we do not find a relationship between this mode of informal learning and the size of the firm in which someone is employed. 


\section{Conclusion and policy implications}

In this paper we found that personal, job as well as firm characteristics are significantly related to human capital investments of S\&Es. However, there are remarkable differences between formal training and the different modes of informal learning we distinguished: self-teaching, learning from colleagues, and performing tasks from which one can learn.

Our estimation results show there is no complementarity between S\&Es' level of initial education and participation in formal training. However, those with a master degree more often perform tasks from which they can learn, although they learn significantly less from their colleagues than S\&Es with a bachelor degree. Female S\&Es have a different pattern of informal learning than males. They spend less time on self-teaching, but more often learn from their colleagues. S\&Es with more work experience participate in formal training less often but do not have significantly less informal learning. This shows that in particular formal training is concentrated at the beginning of a career, as expected by human capital theory. Moreover, S\&Es with long firm tenures learn significantly less from their colleagues. This shows that skill spill-overs at work are particularly related to firmspecific skills. We also found that S\&Es who perceive to have a skill gap more often participate in all three modes of informal learning. However, they do not bridge their skill gap by greater participation in formal training. This shows that in particular informal learning may be a substitute for a lack of earlier human capital investments.

Our estimation results clearly show that different skill requirements are acquired by different modes of training and learning. S\&Es who are employed in jobs which require a high level of technical knowledge more often participate in formal training, and acquire more knowledge and skills by the tasks they perform. This does not hold for the acquisition of the non-technical skills required in the job. Those employed in jobs which require a high level of general skills, participate significantly more often in all three modes of informal learning we distinguished. Oppositely, S\&Es employed in jobs with high IT skill demands more often participate in formal training, but do not report a significantly higher participation 
in informal learning. Also those employed in jobs which require a high level of management knowledge and skills more often participate in formal training. However, these S\&Es spend less time on self-teaching. S\&Es who are employed in jobs which demand high levels of commercial and financial skills significantly less often participate in formal training, and also spend less time on self-teaching.

Our analyses show that being employed in an innovative firm stimulates most modes of human capital investments. S\&Es who are employed in firms which apply innovative production processes, more often participate in formal training and benefit from the learning potential of their jobs. Organizational innovativeness of the firm is also positively related to S\&Es' participation in both formal training and informal learning. However, the relationship between human capital investments and firm innovations is not straightforward: S\&Es who are employed in firms with many product innovations more often learn from their colleagues and from the tasks they have, but participate less often in formal training.

The competitiveness of the product markets of the firm also matters. As we expected, S\&Es who are employed in firms which sell their products in highly competitive markets or instable product markets, less often participate in formal training. However, there is no significant relationship between the competitiveness of the product markets and investments in informal learning. Finally, as in many other studies, we find that those employed in large firms more often participate in formal training. Our results show, however, that this is partly compensated by a higher degree of self-teaching of the S\&Es who are employed in smaller firms. Remarkably, we do not find any additional sector effects on either formal training or informal learning; this also holds for those employed in the $\mathrm{R} \& \mathrm{D}$ sector.

More in general, we may conclude that both formal training and informal learning are related in particular to job and firm characteristics. This suggests that labour demand characteristics are more important for the human capital investments of S\&Es than labour supply characteristics. Moreover, only high demands for technological knowledge and organizational innovations boost both formal training and informal learning. Conversely, high demands for commercial 
and financial skills are negatively related to both formal training and informal learning.

Having a workforce of S\&Es with up-to-date knowledge and skills is a prerequisite for a competitive economy (cf. Galia and Legros, 2004). Our analyses show that lifelong learning of S\&Es is fostered by innovative firms and suffers when firms face severe competition in their product markets. Therefore, public policies that stimulate innovation also prevent skills obsolescence among S\&Es. Moreover, the competence level of older S\&Es with long firm tenures is most at risk because these workers both participate less often in training, and have less learning opportunities in the workplace. Public policies that aim to diminish labour market shortages of S\&Es by discouraging early retirement of experienced S\&Es should therefore take account of the necessity to keep the human capital of older S\&Es with long firm tenures up-to-date.

\section{References}

Acemoglu, D., 1997. Training and Innovation in an Imperfect Labour Market. Review of Economic Studies 64, 445-464.

Acemoglu, D., Pischke, J.-S., 1998. Why do firms train? Theory and evidence. Quarterly Journal of Economics 113, 79-119.

Allen, J., De Grip, A., 2007. Skill Obsolescence, Lifelong Learning and Labor Market Participation. ROA-RM-2007/6, Maastricht University, Maastricht.

Arrow, K.J., 1962. The Economic Implications of Learning by Doing. Review of Economic Studies 24, 155-173.

Barron, J.M., Berger, M.C., Black, D.A., 1997. How Well Do We Measure Training? Journal of Labour Economics 15, 507-528.

Bartel, A.P., Sicherman, N., 1993. Technological Change and Retirement Decisions of Older Workers. Journal of Labor Economics 11, 162-183. 
Bassanini, A., Booth, A., Brunello, G., De Paola, M., Leuven, E., 2005. Workplace training in Europe. IZA Discussion paper 1640, Bonn.

Becker, G., 1964. Human Capital: a Theoretical and Empirical Analysis, with Special Reference to Education. NBER, New York.

Borghans, L., Golsteyn, B., De Grip, A., 2007. Werkend leren. Economisch Statistische Berichten 92, 260-263.

Bresnahan, T.F., Brynjolfsson, E., Hitt, L.M., 2002. Information Technology, Workplace Organization, and the Demand for Skilled Labor: Firm-Level Evidence. Quarterly Journal of Economics 117, 339-376.

Burke, L.A., Baldwin, T.T., 1999. Workforce training transfer: A study of the effect of relapse prevention training and transfer climate. Human Resource Management, 38,: 227-241.

Coates, G., Duffy, A., Hills, W. Whitfield, R., 2007. A preliminary approach for modeling and planning the composition of engineering project teams. Proceedings of the Institution of Mechanical Engineers Part B, Engineering Manufacture 221, 1255-1265

Dickerson, A., Green, F., 2004. The growth and valuation of computing and other generic skills, Oxford Economic Papers 56, 371-406.

Eraut, M., 2000. Non-formal learning and tacit knowledge in professional work, British Journal of Educational Psychology 70, 113-136.

Groot, L.F.M., De Grip, A., 1991. Technological Change and Skill Formation in the Bank Sector. Economics of Education Review 10, 57-71.

Galia, F., Legros, D., 2004. Complementarities between obstacles to innovation: evidence from France. Research Policy 33, 1185-1199.

Ichniowski, C., Shaw, K., 2003. Beyond incentive pay: Insiders' estimates of the value of complementary human resource management practices. Journal of Economic Perspectives 17, 155-180.

Killingsworth, M.R., 1982. "Learning by Doing" and "Investment in Trai $\neg$ ning": A Synthesis of Two "Rival” Models of the Life Cycle. Review of Economic Studies 49, 263-271.

Kumar, S., Kent Hsiao, J., 2007. Engineers Learn “Soft Skills the Hard Way”: Planting a Seed of Leadership in Engineering Classes. Leadership \& Management in Engineering 7, 18-23, 
Lavoie, M., Finnie, R., 1998. The early careers of engineers and the accumulation of skills in the Canadian economy. Economics of Innovation \& New Technology 7, 53-69.

Lavoie, M., Roy, R., Therrien, P., 2003. Growing trend toward knowledge work in Canada. Research Policy 32, 827-844.

Loewenstein, M.A., Spletzer, J. R., 1999. General and Specific Training. Evidence and Implications, Journal of Human Resources 34, 710-733.

Lynch, L.M., Black, S.E., 1998. Beyond the incidence of employer-provided training. Industrial and Labor Relations Review 52, 64-81.

Machin, S., Van Reenen, J., 1998. Technology and Changes in Skill Structure. Evidence from Seven OECD Countries. Quarterly Journal of Economics 113, 1215-1244.

Maximiano, S., Oosterbeek, H., 2006. On the determinants of workers' and firms' willingness to train. Paper presented on EALE Conference 2007.

McDowell, J. M., 1982. Obsolescence of Knowledge and Career Publication Profiles: Some Evidence of Differences among Fields in Costs of Interrupted Careers. American Economic Review 72, 752-768.

Mincer, J., 1974. Schooling, Experience and Earnings. Columbia University Press, New York.

Mincer, J., 1989. Human Capital Responses to Technological Change in the Labor Market. NBER Working Paper 3207, Cambridge, MA.

Nelen, A., De Grip, A., 2009. Why do part-time workers invest less in human capital than fulltimers? Labour (forthcoming)

Neuman, S., Weiss, A., 1995. On the Effects of Schooling Vintage on Experience-Earnings Profiles: Theory and Evidence. European Economic Review 39, 943-955.

OECD, 1999. Employment Outlook. OECD, Paris.

Piva, M., Vivarelli, M., 2004. The determinants of the skill bias in Italy: R\&D, organisation or globalisation? Economics of Innovation \& New Technology 13, 329-347.

Jen, Q.-J., 2008. Exploring career stages of midcareer and older engineers. When managerial transition matters. IEEE transactions on engineering management 55 , 82-93. 
Rosen, S., 1972. Learning and Experience in the labor market. Journal of Human Resources 7 , 326-342.

Shields, M., 1998. Changes in the determinants of employer-funded training for full-time employees in Britain. Oxford Bulletin of Economics and Statistics 60, 189-214.

Sicherman, N., 1991. Overeducation" in the Labor Market. Journal of Labor Economics 9, 101122.

Sicherman, N., Galor, O., 1990. A Theory of Career Mobility. Journal of Political Economy 98, 169-192.

Smoorenburg, M.S.M., Van der Velden, R.K.W., 2000. The training of school-leavers. Complementarity or substitution? Economics of Education Review 19, 207-217. 